\title{
Histone-Lysine N-Methyltransferase
} EHMT1

National Cancer Institute

\section{Source}

National Cancer Institute. Histone-Lysine N-Methyltransferase EHMT1. NCI Thesaurus.

Code $C 75328$.

Histone-lysine N-methyltransferase EHMT1 (1298 aa, $141 \mathrm{kDa}$ ) is encoded by the human EHMT1 gene. This protein plays a role in histone methylation. 